CARNETS OE Carnets de géographes

GÉOGRAPHES.

2| 2011

Espaces virtuels

\title{
Socio-religious desegregation in an immediate postwar town
}

Jaffna, Sri Lanka

Delon Madavan

\section{(2) OpenEdition}

Journals

Electronic version

URL: http://journals.openedition.org/cdg/2711

DOI: $10.4000 / \mathrm{cdg} .2711$

ISSN: $2107-7266$

Publisher

UMR 245 - CESSMA

Electronic reference

Delon Madavan, "Socio-religious desegregation in an immediate postwar town », Carnets de géographes [Online], 2 | 2011, Online since 02 March 2011, connection on 07 May 2019. URL : http:// journals.openedition.org/cdg/2711; DOI : 10.4000/cdg.2711

\section{(c) $)(9)$}

La revue Carnets de géographes est mise à disposition selon les termes de la Licence Creative Commons Attribution - Pas d'Utilisation Commerciale - Pas de Modification 4.0 International. 


\title{
Socio-religious desegregation \\ in an immediate postwar town \\ Jaffna, Sri Lanka
}

Delon MADAVAN

\author{
$\mathrm{PhD}$ candidate and Junior Lecturer in Geography \\ Université Paris-IV Sorbonne \\ Laboratoire Espaces, Nature et Culture (UMR 8185) \\ delonmadavan@gmail.com
}

\begin{abstract}
The cease-fire agreement of 2002 between the Sri Lankan state and the separatist movement of Liberalisation Tigers of Tamil Eelam (LTTE), was an opportunity to analyze the role of war and then of the cessation of fighting as a potential process of transformation of the segregation at Jaffna in the context of immediate post-war period. Indeed, the armed conflict (1987-2001), with the abolition of the caste system by the LTTE and repeated displacements of people, has been a breakdown for Jaffnese society. The weight of the hierarchical castes system and the one of religious communities, which partially determine the town's prewar population distribution, the choice of spouse, social networks of individuals, values and taboos of society, have been questioned as a result of the conflict. Indeed, the town of the immediate post-war has a different structuring and functionality model from that of before the war. Identity-based segregation, associated to belonging to a caste, is thus in phase of disappearance. However, the end of the caste system (discriminations, socio-economic interdependence) does not prevent the persistence of the caste reality (endogamy, the bonds of solidarity by caste). At the same time, the existence of a large diaspora is the source of a new factor of segmentation in the society. Their support plays a leading role in the reconstruction, economic development of the town and the upward mobility of people. Finally, if inhabitants live in large majorities in neighborhoods traditionally occupied by their caste, the process of space desegregation seems to be engaged.
\end{abstract}

Keywords: Urban segregation, Territory, Identity, Caste, Religion, Jaffna, Tamil, Sri Lanka 


\section{Introduction:}

The segmentation of societies around the world and people's will to live among their peers have led researchers to develop the concept of segregation to reflect the socio-spatial inequalities that exist in urban spaces. This segregation, which includes both residential spaces than productive or meeting spaces, took place on economic, ethnic, religious or racial bases. Nevertheless, whatever the segmental factor underlying the segregation, "inequalities are somehow absorbed and do not generate a questioning of all" (Navez-Bouchanine, 2001, translated from french). Thus, differentiations and urban partitions do not lead to a rupture or to the autonomy of segregated communities. This heterogeneous and hierarchical distribution of the population does not question the norms and values of the society which, according to circumstances, can be internalized by force.

One can wonder about the fate of cities that emerge from war and whose communities have ceased to live together because of armed conflict. The cease-fire of 2002 between the Sri Lankan state and the separatist movement of Liberalisation Tigers of Tamil Eelam (LTTE) ${ }^{1}$ has been an opportunity to study the case of the city of Jaffna in Sri Lanka which came out of fourteen years of armed conflict (1987-2001). This town, which is the capital city of the northern province, has the particularity of being the only province of the island where the Tamil community represents over $80 \%$ of the population and where the practice of Hinduism is predominant (see Figure 1). As such, the logics of settlement in the town are influenced, as in India (Landy, 2002), by the weight of segmentation due to belonging of caste ${ }^{2}$ and religion.

At the same time, political factors have played an important role on the geography of the population of this city which was one of the major theaters of the war (Hoole et al., 1990 ; Madavan, 2007). Indeed, as in other cities affected by war (Rosière, 2007, Hasbullah, 2001 ; Tratnjek, 2006), the armed conflict has been the source of a "coercive modification of settlement ${ }^{3 \prime}$ with the forced displacement of tens of thousands of people in the island and abroad. The city of Jaffna which in the last official census of $1981^{4}$ counted 118215 inhabitants, saw its population steadily escape from the frontline zone. In 1995, following the onslaught of the Sri Lankan army, almost all the inhabitants deserted the town and tried to follow the rebels in the jungles of Wanni. The cease-fire agreement between the warring

1. LTTE is an independentist movement, founded in 1976 by Velupillai Prabhakaran, whose stated aim is to defend the Tamils of Sri Lanka. For this, the organization claims the right for Tamils to self-determination and to an independent statehood, the Tamil Eelam in the north and east of the island. To get their independence, the Tigers engaged in an armed struggle with the central government. The LTTE did not hesitate to use force to eliminate its political rivals in order to assert itself as the sole representative of the interests of Tamils. The Tigers also used suicide bombings as a means of action to advance their cause (Indian Prime Minister Rajiv Gandhi, the President of the Republic of Sri Lanka Ranasinghe Premadasa, etc.). The LTTE emerged since 1987 as the key player in national politics. Indeed, the movement managed to cope with various attacks of the government army and even the Indian forces which tried for a time to disarm it by force. The Tigers run as a sovereign State the territories they controlled in the north and east of the country. The military defeat of the Tigers in May 17, 2009 undermined the movement. Its historic leader, Prabhakaran, is dead and the LTTE lost all its territorial possessions in the island. Nevertheless, the separatist movement still has the strong support from the Tamil diaspora and has not abandoned its dream of creating an independent state for Tamils in Sri Lanka.

2. The caste system is a hierarchical division in Hindu societies according to a so-called hereditary "purity" of endogamous groups. The castes are frequently associated with archetypal activities, but which is no longer necessarily followed in practice.

3. This expression is used to designate all violent processes (colonization, segregation, expulsion, refoulement, deportation and extermination) implemented by political factors in order to transform the people (Rosiere 2007)

4. No census has been conducted since 1981 in the northern and eastern provinces by the statistical departments of the central government because of the armed conflict. However, the district of Jaffna conducted its own censuses thanks to the cease-fire of 2002 
parties enabled many war-displaced people to return to their town, which had, in 2002, 78331 inhabitants.

The traditional society of Jaffna has been also disrupted by the conflict. The weight of the hierarchical caste system and the religious communities that traditionally determine the choice of a spouse, individuals' social networks, society prejudices and taboos, have been called into question as a result of the conflict. The Tigers, by their attitude and their stance, helped to transform it. Indeed, in an effort to unite all Tamils around their movement, the LTTE leaders highlighted the need to be united against the Sinhala oppression. Consequently, the separatist movement leaders declared themselves openly hostile to the caste system and affirmed their will to do everything to eradicate it. This position increased the sympathy of the lower castes for the paramilitary movement whereas many Vellalar ${ }^{5}$ saw in this attempt a way of weakening their influence in the Jaffnese society. In areas under its control (see Figure 1), the LTTE abolished all distinctions of caste and made it a taboo subject for the entire Tamil community in the island. The separatist movement contributed, through its authority and the fear it inspired to people, in removing the marks of humiliation that still existed in the 1980s (Pfaffenberger, 1982).

5. Vellalar are members of rice farmers' caste. This social group dominates the social pyramid in Jaffna and derives its authority from the possession of land. 
Figure 1 :Distribution of ethnic communities in Sri Lanka

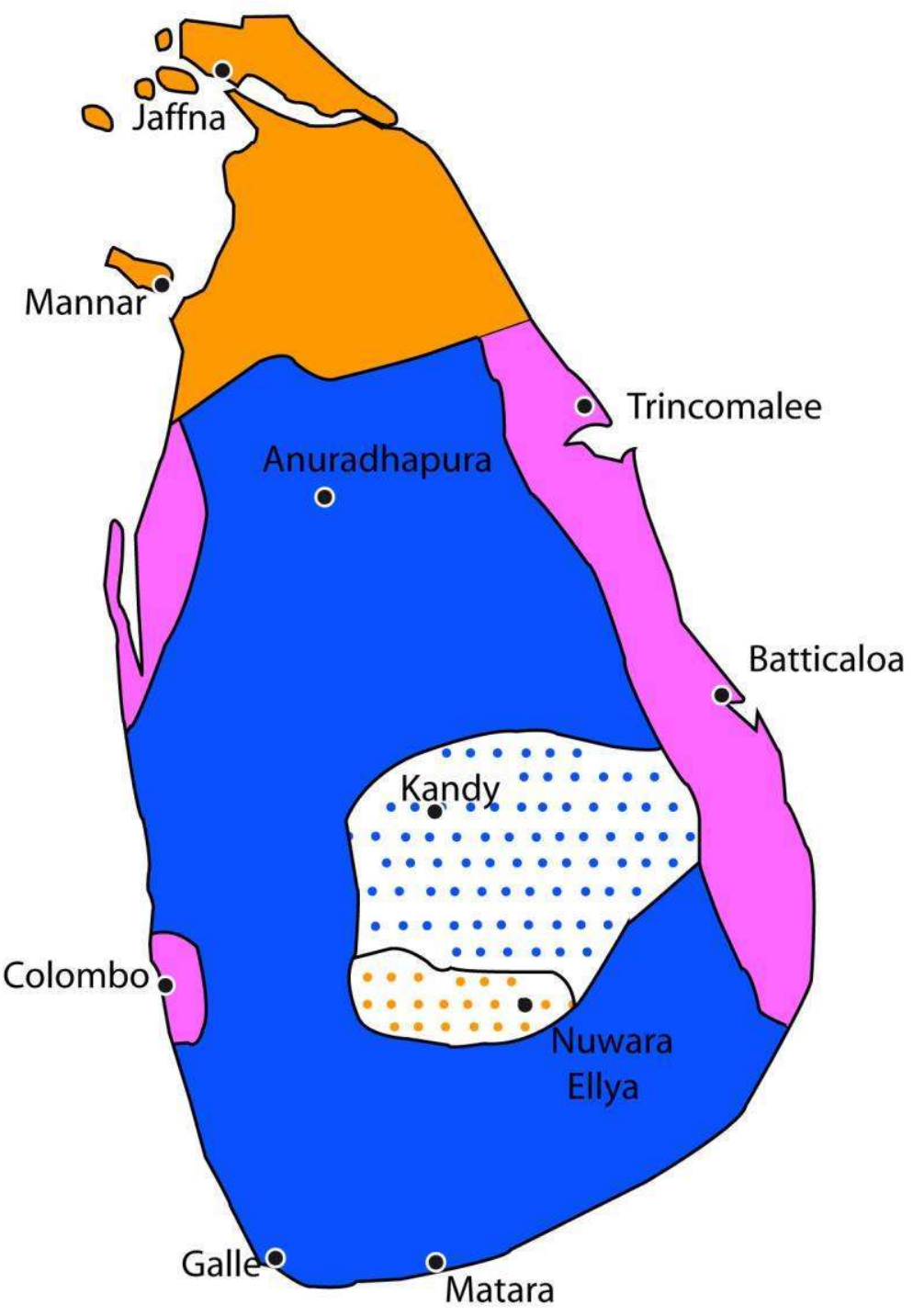

Legende

Sinhalese majority zone (> $80 \%$ )

$\square$ Tamil majority zone (> 80\%)

-. Sinhalese majority zone

with important Tamil and Muslim minorities presence

Tamil majority zone with an important Sinhalese minority

Tricommunautarian zone

source : Meyer (2001) 
Figure 2 : Geopolitical situation of Sri Lanka (2003)

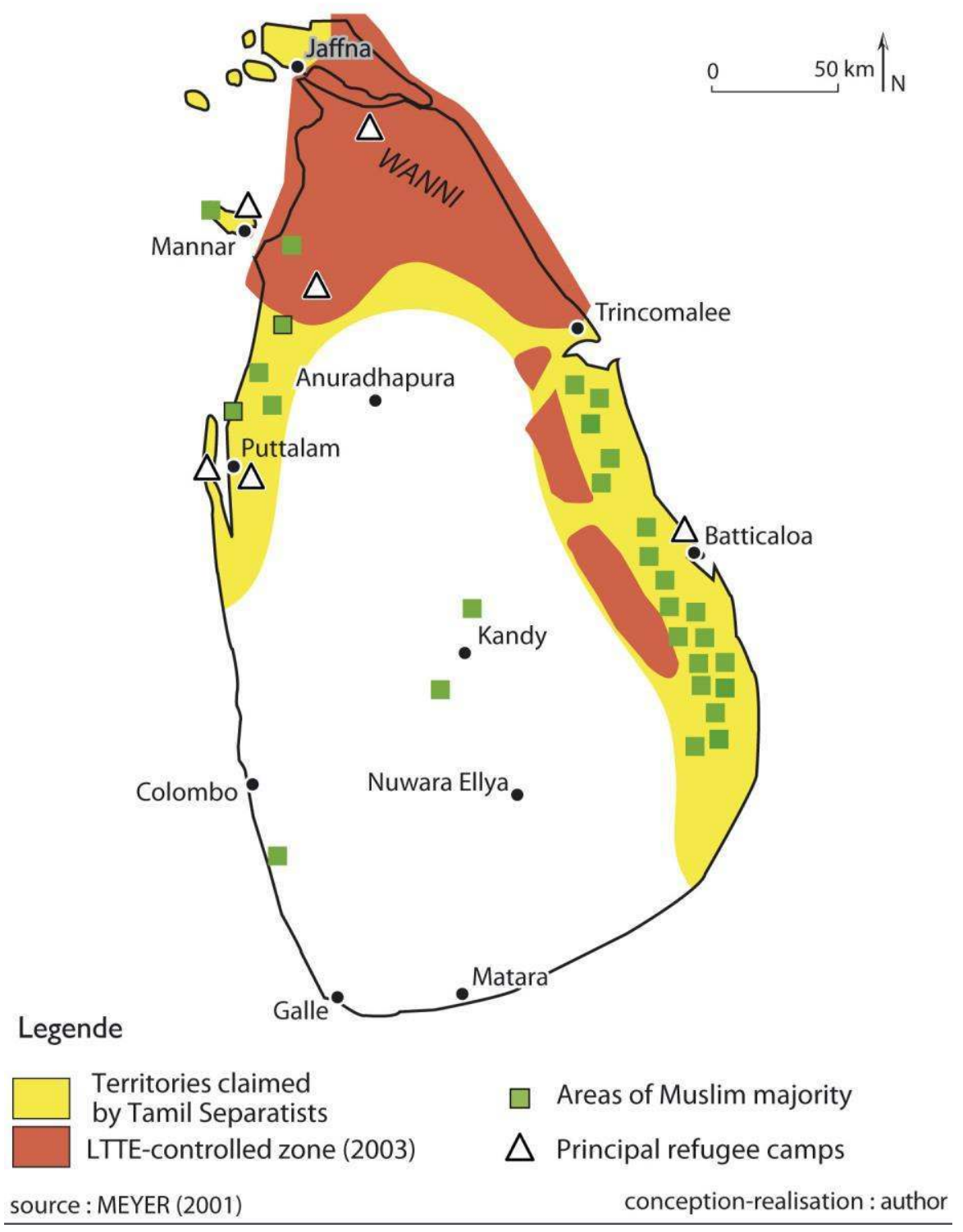

At the same time, the Tigers denied any religious distinctions among Tamils which might have singled out and cut off from the movement the members of any faith group. But the LTTE coped with the desire of Muslims to be recognized as community in itself with their own representatives. Faced with the hostility of Muslims from the eastern province against the creation of an independent Tamil State, the LTTE accused the members of this community in the north of being informants of the army. In October 1990, the Tigers ordered the 75000 Muslims living in the northern province to leave it. The separatist movement wanted to expel a community considered dissident and strengthened the mono-ethnic character of the province. The choice of expelling a population that had lived for generations in Jaffna, caused severe trauma. These Muslims, the majority of whom did not speak Sinhalese and regarded Jaffna as their homeland, were forced to leave everything overnight whereas the majority Tamil dared not show its disagreement for fear of reprisals from the LTTE militants. The main Tamil separatist movement profoundly changed the Jaffnese society. Indeed, the Tigers used all their authority to overcome the caste system but they also undermined the ideal of religious tolerance that had hitherto characterized the city.

By questioning the evolution of the society through a spatial approach, we will see wether fifteen years of war and the end of the conflict were or not at the origin of a transformation of the segregated character of the town. For this, we will first consider the evolution of population settlement (colonization, exclusion, conflictuality) and segregation in 
Jaffna until the imminent pre-war in 1987. Then, we will examine wether the consequences of the war and its ending have changed the society and the urban model of Jaffna during the immediate postwar period (2002-2005).

To answer this question, we will rely on interviews with 45 residents of Jaffna town, conducted in 2005, during the cease-fire that had been a lull in the conflict and which made possible the return of war-displaced people. These interviews were conducted, in Tamil, addressing, in different parts of the city, passersby, shopowners or employees of the administration of the Jaffna Municipal Council.

\section{I/ A city marked by cultural and social differences among its people}

\section{A/ Jaffna or religious coexistence}

Jaffna partly owes its preponderance over other Tamil towns of the island to the existence since the thirteenth century, of the Tamil kingdom of Jaffna. Although the presence of Tamils in Ceylon is much older, there had until then no Tamil kingdom as such but different kingdoms with, at their head, Sinhalese or Tamil kings. Until the thirteenth century, the various communities of the island lived together, as in the north west of Ceylon in Rajarata, whose main capital was Anuradharapura (cf. Figure 2). At the end of the thirteenth century, following the invasion by sovereigns from India, the Rajarata, which was the main population household of Ceylon, was abandoned by its inhabitants. They fled the area after it became unhealthy due to the destruction of dams by the invaders from India, the spread of malaria and the difficulty to cultivate land, and therefore migrated to more favorable zones. The Sinhalese settled into the southwest, while the Tamils, under the influence of whom the worship of Shiva begins to prevail, head to the north of the island in the Jaffna peninsula (Meyer, 2001). The latter became the main Tamil population household in which the practice of Hinduism continues to flourish. Although Jaffna is a modern town with many of its current appearances still influenced by colonial period, the city remains in the eyes of its inhabitants the heiress of the kingdom of Jaffna and therefore the historical capital of the Tamils in the island.

If the practice of Hinduism is predominant, there is a long tradition of tolerance and coexistence between different religions groups in Jaffna. At the time of the domination of Tamil kings, the accounts of Western travelers mentioned the presence of Muslims living peacefully with the indigenous population that was predominantly Hindu (Jaffna Municipal Council, 1974). Islam took root in Jaffna with the establishment of Arab traders from the Middle East, attracted by the trade of beads, and who married Tamil women. After European settlement, it was mostly Muslims from India who came to strengthen this community who traditionally held a significant position in the commercial sector of the city. While sharing the Tamil as their mother tongue, the Muslims of Jaffna, like in the rest of the island, used to consider religion as the identity marker which must prevail against the language. With European colonization, a new religious community emerged, thanks to the strenuous efforts of Christian missionaries, both Catholic and Protestant. Despite a period of high tensions between Hindus and Catholics from the sixteenth to the early seventeenth century, this coexistence of different religions resulted in a spatial distribution of religious communities. By the second half of the nineteenth century, the city of Jaffna seemed to have three distinct areas: coastal areas, the "European town" and the "Hindu town" as neatly set forth explained by Balasundarampillai: 
"The European part of the town, 'Parankitheru' had European residential areas ware houses, the administrative area developed with the establishment of katchcheri ${ }^{6}$. The Chundikuli ${ }^{7}$ was brought under this area. This part had large houses with verandahs, courtyards and compounds. Roads were constructed on grid models with high intensity. The costal area consisted of Karaiyoor, Pasayoor and Alupanthi, fishing boat building; boat repairing and port activities were confined to this area. The Western part of the town was known as 'Hindu Town' of Vannarponnai. English educated people of hindu origin and the affluent trades folk mainly inhabited this area."

(Jaffna Municipal Council, 1974, no numbering)

We find in Jaffna the model of dual colonial towns with the juxtaposition of two contrasting parts: the "European town" and the "indigenous town". This duality is also reflected through the opposition between the Christian southern part of Jaffna, comprising the coastal areas listed by the author and the "European town", and the northern part which is predominantly Hindu. The eastern part of the town is marked by the presence of the Muslim community. The location of religious buildings exemplifies this religious segregation in the municipality (cf. figure 3 ). 


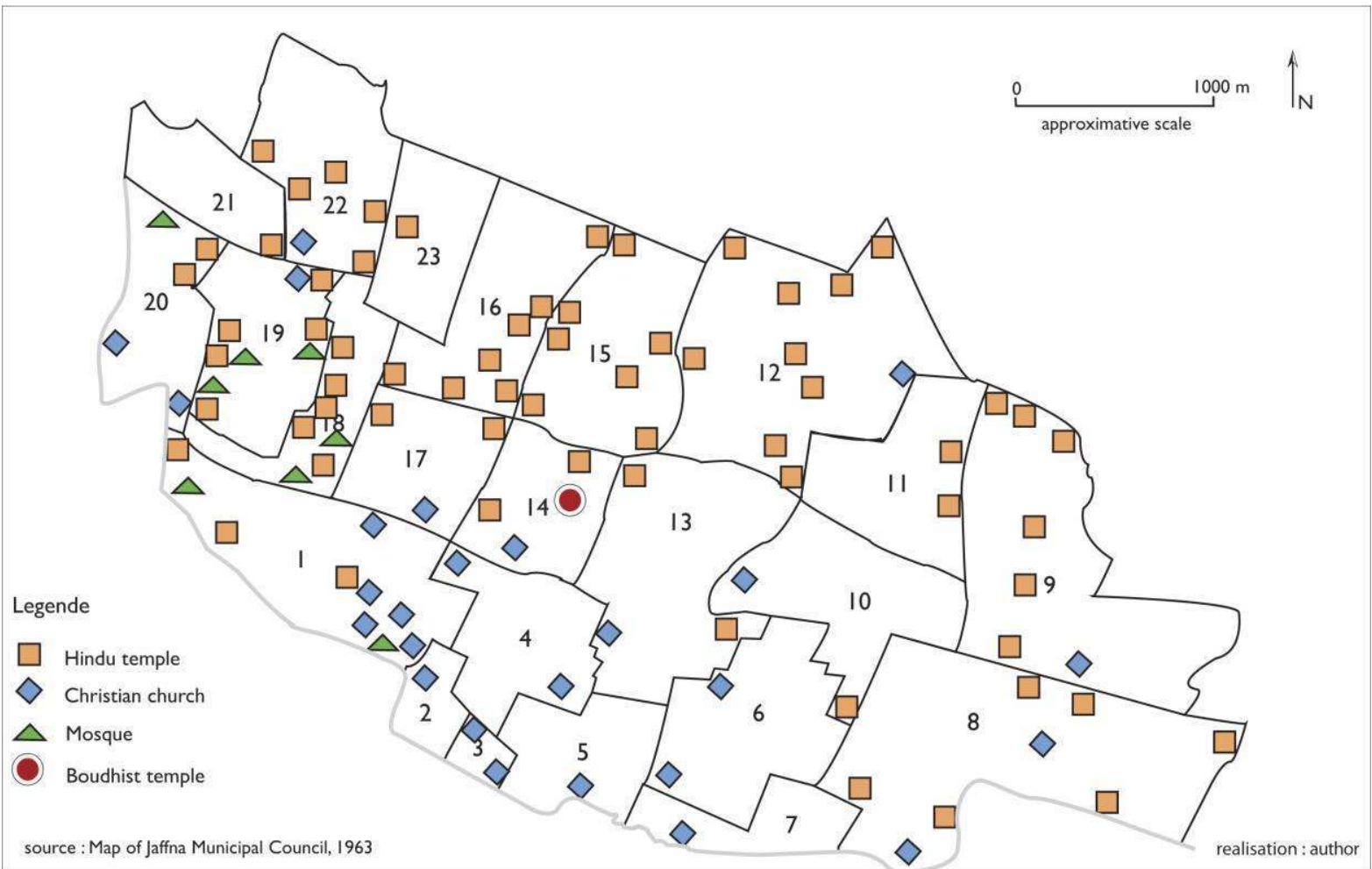

List of the 23 districts of Jaffna Municipal Council

\begin{tabular}{|c|c|c|c|}
\hline Number of district & Name of district & Number of district & Name of district \\
\hline 1 & Fort & 13 & Chundicully \\
\hline 2 & Gurunagar West & 14 & Station \\
\hline 3 & Gurunagar East & 15 & Kailasapillayar \\
\hline 4 & Cathedral & 16 & Kandaswela \\
\hline 5 & Mathews & 17 & Hospital \\
\hline 6 & Koiyatotom & 18 & Bazaar \\
\hline 7 & Passaiyoor & 19 & New Mosque \\
\hline 8 & Columbuthura & 20 & Navanthura \\
\hline 9 & Ariyalai East & 21 & Old Mosque \\
\hline 10 & Ariyalai West & 22 & Navanthura West \\
\hline 11 & Kalaimalar & 23 & Navanthura East \\
\hline 12 & Nallur & & \\
\hline
\end{tabular}

Source : author, 2007

The recognition of the existence of a Muslim cultural zone in the city appears in the official name given to two areas they occupy: New Mosque and Old Mosque and the presence of six Muslims colleges. Similarly, the seven mosques in Jaffna are all located in the western part of the city (see Figure 2). The commercial district, called Bazaar, is another area where Muslim merchants traditionally used to occupy a prominent place.

The second cultural area is the Christian area which is concentrated in the southern part of the city. The evangelization of the population has taken different forms. Thus, the first conversions, concerning mostly fishermen, conducted by the Portuguese, are deemed to have been made under threat. The Dutch and the British, promoted the conversions by providing facilities and benefits to the converted. Balasundarampillai distinguished coastal districts in the Christian area, which he pinpointed as Christian fishermen neighborhoods, and the "European City", the residential and administrative quarters shaped by Westerners. This part 
of the city was strongly influenced by the European presence. The harbor and the fort were in a sense the epicenter from which the Europeans created the modern city of Jaffna and started converting the fishermen who were there. Thus, it is not surprising to note that this Christian area, whose center is Main Street, concentrates the principal buildings erected by Europeans: the Dutch fort, around which the main city roads converge, the majority of Christian buildings, like the Cathedral of Jaffna, and administrations buildings, like katchcheri which serves as headquarters to the district of Jaffna. This part of the town houses the largest hospital in Jaffna and the main business district.

The 'Hindu town' of Jaffna had as its center, the temple of Kandaswamy at Nallur. The rise of the cult of Shiva in Jaffna went hand in hand with the advent and growth of the Kingdom of Jaffna. Kandaswamy temple is the sole princely structure built by the kings of Jaffna in the island. This temple, served by a high-ranking Brahman, strengthened the role of Jaffna as great Hindu center at Sri Lanka. The map of religious buildings in the Jaffna Municipal Council shows the importance of the Hindu community (see Figure 2). In fact, Hindu temples represent nearly three-quarters of the religious buildings of the city. The Hindu area, which includes the northern and eastern parts of the municipality, is considered by inhabitants as the true original center of the town. The Hindu elite defended the worship of Shiva as a founding element of Tamil identity against the endeavours towards a Christianization of the population by Europeans. The defense of the Hindu identity led to the creation of new Hindu temples and schools, such as the Hindu College to compete with prestigious Christian schools. 


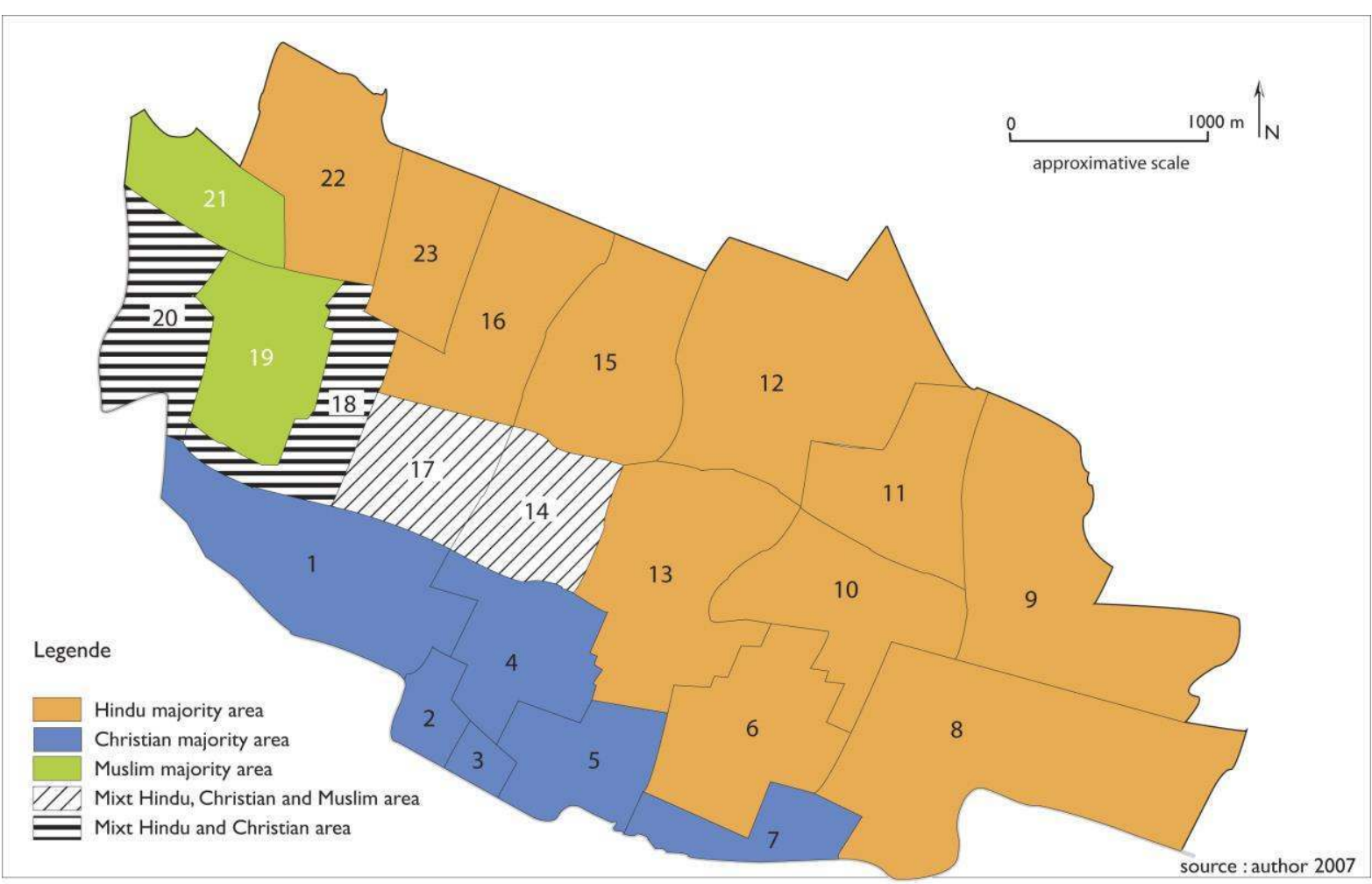

Figure 4 : Distribution of religious communities in Jaffna by district

Religious segmentation in Jaffna is the result of the arrangement of various precolonial and colonial legacies. The arrival of alien populations (Arabs and Europeans) was accompanied by the development of two new religions (Islam and Christianity) in an Hindu population household. The religious segmentation of Jaffnese society results in a segregation distinguishing three confessional zones. However, it is important to note that these boundaries are not absolute and that within areas known to be predominantly Christian or Hindu, we can find a significant minority of the other religion. This inter-religious coexistence was also reflected by the presence of a Sinhalese Buddhist community, with a temple inside the city until its destruction, in 1987 - for political reasons - by the Tigers. The rebuilding of a Buddhist temple since the reoccupation of Jaffna by the army was a source of tension. This temple was during ceasefire period only frequented by the Sri Lankan soldiers who placed their worship place as high-security zone. We can talk, regarding Jaffna, of a genuine interreligious coexistence.

\section{B/ A society governed by the order of castes}

Hinduism holds a great place in the Tamil civilization and explains the importance of castes in Jaffna (see Table 1). The caste system is deemed particularly rigid in the Jaffna peninsula and has a number of peculiarities. It is difficult to establish the exact number of castes in Jaffna, although the Dutch governor Thomas Van Rhee counted 41 in 1687 (Pfaffenberger, 1982). Indeed, caste divisions are made, as shown in the simplified table of caste in Jaffna (see Table 1), along professional but also religious standards. Thus, it distinguishes the Hindu carpenters and their Christians fellows. Moreover, within the same group sharing the same profession and same religion, there are sub divisions according to their geographical location. Thus, the different Christian fishermen's neighbourhoods, in the south of the city, have distinct identities that translate into matrimonial alliances most often within their own community. 
Tableau 1: Simplified table of the hierarchy of castes in Jaffna

\begin{tabular}{|c|c|c|}
\hline CASTE & ACTIVITY & STATUS \\
\hline Vellalar & Rice farmers & High Caste \\
\hline $\begin{array}{l}\text { Karaiyar } \\
\text { Paravar }\end{array}$ & Fishermen & Fishermen \\
\hline Thatcher & Carpenters & \multirow{3}{*}{ Kudimai } \\
\hline Visvakarma & Blacksmiths & \\
\hline Koviyar & Domestics & \\
\hline Nalavar & Extractors toddy $^{8}$ & \multirow[b]{3}{*}{ Adimai } \\
\hline Pallar & Porters, servants, agricultural workers & \\
\hline Paraiyar & Drum players & \\
\hline
\end{tabular}

Source : author 2007

The group that dominates the social pyramid in Jaffna is that of the rice farmers, called Vellalar, which derives its authority from the possession of the land. This caste, which has long been numerically the largest community in the city, considers itself as the legitimate keeper of the existence of the hierarchical caste society according to the "purity level" of a particular group of individuals. In this pyramid of castes, three groups were long distinguished under the Vellalar caste: the kudimai, the adimai and finally Fishermen's castes. Kudimai castes counted artisans and employees of Vellalar's houses and they were their clients. Therefore they had rights and duties that could not be cashed. Conversely, adimai castes, which counted those who lived by tilling the soil, or activities considered impure, were treated as untouchables. They long lived in separate huts and were maintained in their inferiority status by humiliations and discriminations. Thus, Vellalar had prohibited persons from impure castes to have access to major temples in the city, as in the case of the Kandaswamy temple. Fishermen, by the nature of their activity, were independent from Vellalar, to whom they owed no service, and they were not, unlike kudimai, Vellalars' clients. Their relative independence led Vellalar to marginalize this community who could manage without them.

Despite important changes under European domination", the existence of this hierarchy has not been questioned. The incitation, by Dutch, then British missionaries, to convert - in exchange for a possibility of upward social mobility - favored the evangelization of some adimai castes such as the Pallar or Nalavar but also some Vellalar who wished to preserve their privileges. It is in the fishermen's community that most conversions to Catholicism have been recorded. The Western impact is not negligible in this caste society. Under British rule, the Vellalar have, thanks to their excellent education in English, widened their political, economic and cultural influences, both in Jaffna and the rest of the island. The development of capitalism enabled craftsmen to become richer. The British decision in 1844, banning any form of slavery, put a definitive end to the distinction between kudimai and adimai, even if they remained in the eyes of Vellalar, untouchables. However, access to education enabled some of these castes to experience significant upward social mobility. Thus, members from the Nalavar caste in the district of the Cathedral converted to Christianity and have mostly abandoned the traditional activity they used to practice. Some members of this caste took advantage of the educational springboard to overcome its old

8. The toddy is palm wine produced from fermented palm sap.

9. The northern part of the island fell successively under the control of the Portuguese (1619-1658), the Dutch (1658-1796)

and finally the British (1796-1948). 
image and gain access to positions in administration and the education sectors. On the contrary, other castes (Pallar, Paraiyar), even though they also converted to Christianity, which did not help ridding them of their stigma, hardly benefited from the opportunities provided by schooling and continued to suffer humiliations and discriminations.

The conversion of a significant part of the population to Christianity and the social advancement of certain castes did not signify the death of the caste hierarchy. Instead, even within the Christian community, considerations of castes did not disappear. The testimony, of a forty-year-old Christian man from the Pallar caste about his childhood, perfectly illustrated the discrimination that his community used to face, at least up to the 1980s:

Author - Can you give me examples of discrimination you have suffered because of your relevance of your caste?

Interlocutor - When I was young, the people of my caste, when we went into a tea shop, we must not drink from a glass like everyone else, but from a tin which was reserved for our caste people. I also remember a job interview to which I went on the recommendation of a Catholic nun. At this meeting which was attended by four other candidates, the recruiter asked other people to sit, then turned to me and said 'get out', declaring it was not possible to send people from my area, and therefore my caste, to attend a job interview. Faced with such a humiliation, I thought of killing this recruiter and, above all, to reject this Jaffnese society which despised me so much.

(Interview conducted in March 2005 in Jaffna)

The importance of castes in Jaffnese society is clearly reflected through marriages, which are mostly arranged and where caste endogamy is strictly enforced. Indeed, the main concern of parents is often to preserve the honor and the respectability of the family, avoiding at all costs any caste misalliance, which would result in the exclusion of the family by other members of the caste and would result in breaking up the most important solidarity and sociability bond in Jaffnese society.

If we are witnessing the beginning of a process of challenges of the caste system (abolition of the distinction between kudimai/adimai), this latter is still tough. Discriminations linked to this system existed even between Christians and it is not easy for everyone to overcome his inferior condition. Parallel to this, strict observance of the caste endogamy ensures the continuity of the "purity" and thus the maintenance of the respective status in the order of this hierarchical society. Under these conditions, the bonds of social and economic interdependencies linking these different communities remain despite the social distance resulting from a separation in space. 
Like other towns in Hindu societies (Landy, 2002 : 51), the urban structure of Jaffna is also marked by the legacy of segregated model of the Vedic town, with a geographical distribution of castes. However, the study of the very subtle location of castes in the space of the municipality is problematic. Unlike India, there are no statistics on caste in Sri Lanka. A survey conducted among fifteen residents in the town has allowed a development of a map of their perception of the traditional distribution of castes in Jaffna ${ }^{10}$ (cf. Figure 5). The latter recalls the spatial logic of the segmentation of the caste in Indian towns as described by Kalam (Kalam, 2003: 76):

"The purest are closer to the temples, the gods, they are their agents and servants. Those who are the lowest on the scale of the purity tend to be closer to the opposite pole, pollutant. This pole may take the form of a neighborhood for lower castes, this is the case in most Indian regions ... "

Translated from French by the author

In our case, we can distinguish, Muslim districts apart, four distinct spaces. Thus, we find in the northern part of the city, near the sacred temple of Kandaswamy, Vellalar districts. Those near the coast appear to be mainly peopled by fishermen. Between these two spaces, it seems that there probably existed a space occupied by clients of Vellalar, such as Thatchers. However, this space seems to have evolved following the arrival of the Europeans, although we find, in the eastern part of the city, districts where live castes which were traditionally clients of Vellalar. The inner-west, that is to say the Fort and its three northern neighbouring districts (Bazaar, Hospital and Station) created and developed under the European leadership, have a more mixed caste composition. Indeed, this space, which became the center of the European city, attracted Muslim traders, craftsmen as well as Vellalar who wanted to benefit from the dynamism and prosperity created by Europeans.

10. This map was produced through a survey conducted in the field. Of the 45 people surveyed, 15 have agreed to share their perception of the location of castes in the town. For this, we asked them what was in their view the majority caste in the different neighborhoods. Respondents lived in different neighborhoods of the town and were of different socio-economic backgrounds (age, gender, caste, occupation). However, it should be noted that the results must be nuanced. Indeed, two thirds of respondents to my questionnaire had generally refused to talk about the distribution of castes, either because they did not think they would be capable of doing it or because they considered the issue too sensitive. The responses of the sample were overlapping, so I decided to create this map of the perception of the distribution of castes in the town by its inhabitants. 


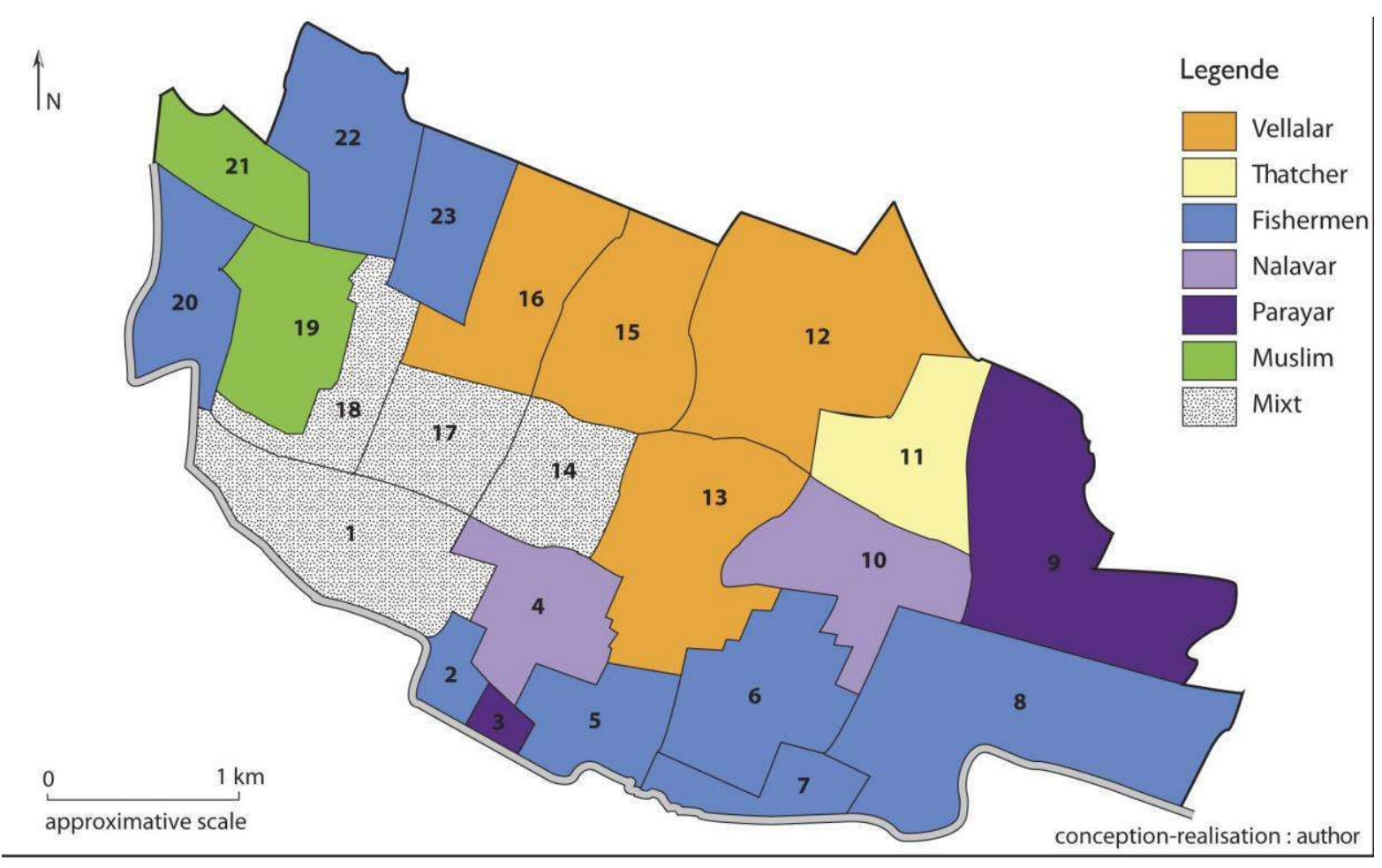

Figure 5 : Perception by inhabitants of castes localisation in Jaffna Municipal Council

The social organization at Jaffna is based on a castes hierarchical structure which results in residential segregation. However, with the development of a dual colonial town, the "European town" becomes the new center of attraction which is at the origin of some transformations of the populations settlement patterns. The evolution of the urban structure of Jaffna until the immediate pre-war finally reveals a situation similar to other towns of Hindu tradition in the indian subcontinent. Despite the severe discriminations that may exist in this society, inequalities do not generate a questioning of the whole system.

The armed conflict, with the banning of the caste hierarchy by the LTTE and the repeated displacement of people has created a break in the traditional modus operandi of this society. During these years of war, It was more difficult, especially in the territories controlled by the separatists, to enforce the rules of caste segregation as strictly. The ceasefire concluded in 2002, was an opportunity to analyze the role of war and of the cessation of fighting as a possible transformation process of segregation in the town in the context of immediate post-war.

\section{II/ The weight of traditional communities during the cease-fire}

\section{A/ The return of the displaced Jaffnese}

After fifteen years of fighting, the cease-fire agreement in 2002 made possible the return of many war displaced people to their original town. But from the 2004 census, there was an important turning point with, for the first time, a decline of population in the Municipal Council, which lost 2198 people in one year (see Table 2). This was paradoxical, because all the displaced people did not return home. The comparative study of the 2001 and 
$2004^{11}$ censuses of the Jaffna Municipal Council (see Figure 5) shows that this decline affected only certain areas. The map of the dynamics of grama sava ${ }^{12}$ in the Jaffna Municipal Council (see Figure 6) shows that it was especially the northern Hindu districts of the city that lost inhabitants while conversely, the southern Christian districts saw their populations grow steadily. By linking this map with the map of the traditional location of castes in Jaffna (see Figure 4), we could notice that it was especially areas traditionally occupied by Vellalar which lost more often, at least 500 people in 3 years. The Vellalar community began to leave the peninsula early, thanks to its financial resources, to get away to the south or abroad. Finally, there was a double migratory movement in Jaffna. Indeed, the poorest Jaffnese, belonging to Fishermen and Parayar castes or even some Muslims returned to the city. They took advantage from a more favorable political environment to gradually return to their homes to rebuild their lives in the city. There was a certain impoverishment of the town, now home to those who have almost nothing, while conversely, the people belonging to the most affluent social groups continued to significantly leave Jaffna, to settle in the capital or abroad, where living conditions were more attractive. The proportionately greater exodus of Vellalar reduced their influence in the local society.

Tableau 2: Population growth in Jaffna (1981-2004)

\begin{tabular}{|c|c|c|}
\hline Year & Number & Growth rate (\%) \\
\hline 1981 & 118,215 & 9.6 \\
\hline 2002 & 78,331 & -33.7 \\
\hline 2003 & 84,226 & 7.5 \\
\hline 2004 & 82,028 & -2.6 \\
\hline
\end{tabular}

Source : Department of Census1981, Divisional Secretary Jaffna and Nallur, 2002, 2003, 2004

11. Sources : Population Census of Jaffna DS and DS / AGA division of Nallur in 2001 and 2004

12. The grama seva is smallest administrative division in Sri Lanka 


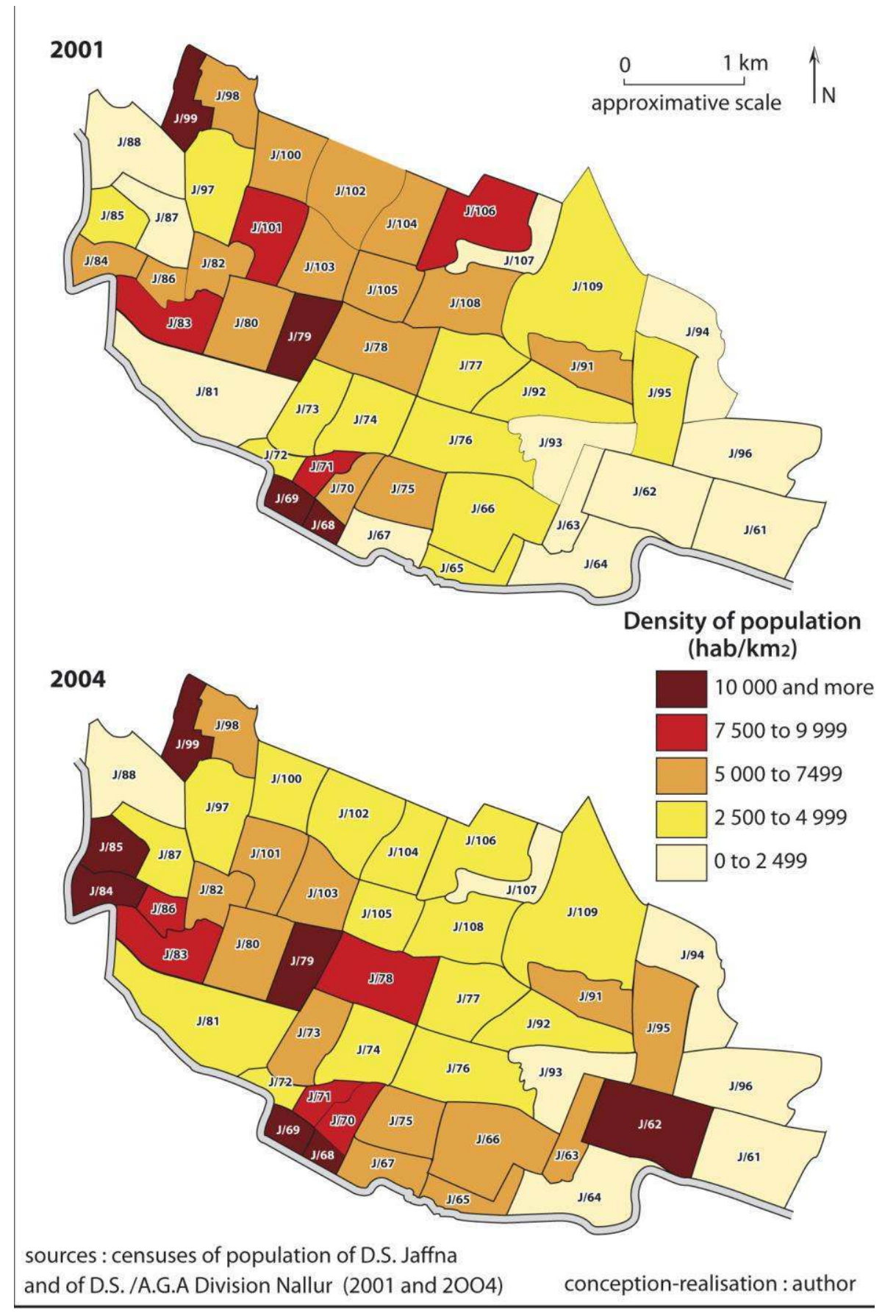

Figure 6 : Density of population in Jaffna (2001-2004)

Sources : recensements de population des D.S Jaffna et des D.S./A.G.A. Division Nallur de 2001 et 2004 ; auteur 2007 


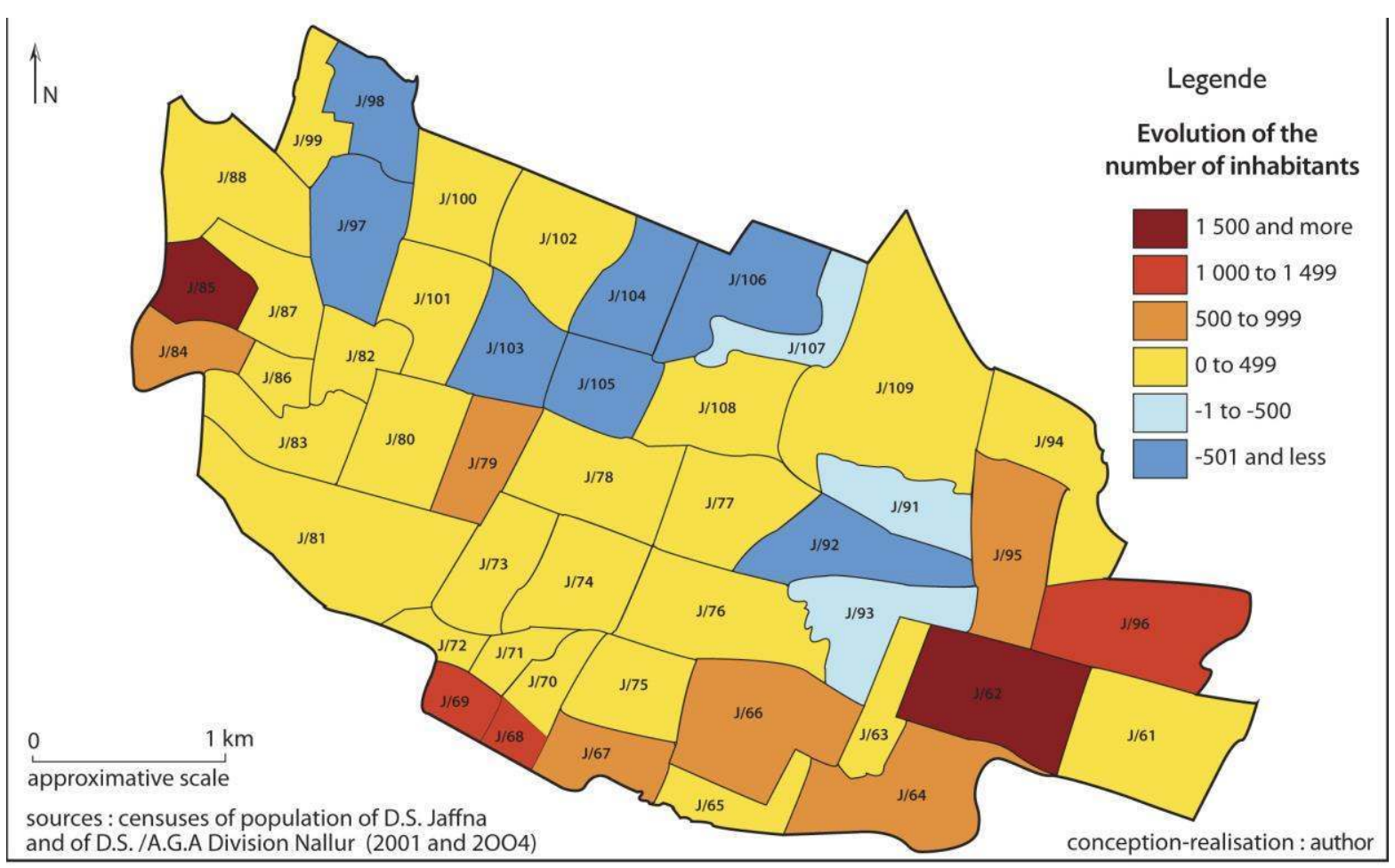

Figure 7 : Dynamism of grama seva

\section{B/ The place of religious communities in Jaffna since the cease-fire.}

In Jaffna, as in the rest of the island, the armed conflict was not at the origin of a secularization of society. Instead, the religious fervor was all the greater. Religion was, for many, the main vehicle through which they coped with the atrocities of war and its consequences. It was therefore not surprising that different faith communities play a particularly important role since the cease-fire in the reconstruction of the city and society. The Hindu and Christian communities were the most important in the city, bringing together more than $97 \%$ of the population of the city while the Muslim community only counted $1,27 \%$.

Table 3 : Religious composition of the population in Jaffna in 2004

\begin{tabular}{|l|l|}
\hline Religious Community & Numbers \\
\hline Hindus & 51040 \\
\hline Christians & 30960 \\
\hline Muslims & 1066 \\
\hline Buddhists & 20 \\
\hline Others & 1140 \\
\hline TOTAL & 84226 \\
\hline
\end{tabular}

Source: Divisional Secretary Jaffna and Nallur, 2004.

The low number of Muslims in Jaffna was primarily due to the forced exile they endured, following the ultimatum of the Tigers in 1990. For seven years, Muslims were far from Jaffna. It was only with the re-conquest of the peninsula by government forces and especially the permission given to resettle by the LTTE that some of them returned. 
According to the principal of Osmania College, only 150 families had returned, when there were between 1500 and 2000 before 1990. It was often the poorest families or merchants who came without their families. The lesser importance of the Muslim community in Jaffna was also reflected by the fact that four Muslim schools were still closed in 2005. The return of some Muslims should not hide the rupture caused by the political decision of Tigers. The forced exodus of Muslims contributed in excluding even further this community from the other Jaffnese. Places of refuge for the Muslims and Tamils were however different. Indeed, most of Tamils tried to take refuge in the jungles of Wanni, remained under LTTE control in 1995. To the contrary, Muslims often headed in 1990 to areas with a high Muslim concentration like in Puttalam and Batticaloa. The attitude of the LTTE vis-à-vis Muslims caused a divorce of this community from the rest of the inhabitants of the city. It may take some time for all religious communities to get together.

Hindus and Christians rapidly took advantage of the cessation of hostilities to restore their religious buildings with donations of their followers in the city and abroad. Thus, the fishermen community of Pasayoor offered on several occasions, the proceeds of a day's fishing of the community to their church. Others volunteers helped in the rebuilding of their religious sanctuary. The reconstruction of these high-places of geosymbols enabled the faithful to restore the sacred space that was a provider of identity markers, of meaning and community solidarity. For their part, religious leaders sought to restore religious ceremonies in churches and temples and reorganized the big festivities interrupted because of war, such as Easter for Christians or the Nallur festival for Hindus.

The cease-fire was an opportunity for religious communities to promote peace through various events. For example, the Catholic Church of Jaffna formed an amateur theater band which played both in the northern and southern parts of the island. This initiative should have helped to bring closer the Tamils and Sinhalese. Some Hindu, Christian and Muslim representatives gathered in an association to promote interfaith peace and fought against the proselytizing of some Christian sects that settled into the city after the cease-fire. Their arrival in Jaffna has been the source of tensions because of their challenges to the two main religious communities. Hindus and Catholics accusing these sects to use money or provide facilities, including those of lower castes (Pallars, Paraiyars), to encourage them to convert. However, some Catholics and Hindus are aware of the need to change the attitude vis-à-vis the lower castes. This is illustrated by the testimony of a Hindu met in Nallur temple:

Author - What do you think of the conversion of members of lower castes to Christianity by evangelical churches?

Interlocutor - The evangelists offer financial or material aid to those who convert to their religion. This explains why some accept. But we have also our responsibility. We must stop stigmatizing the lower castes as inferior to prevent them from being seduced by these sects. It is necessary that the Hindu society evolves towards more equality to a void such conversions and even make the lower castes want to get back to Hinduism.

Interview conducted in February 2005.

The reconstruction of religious buildings embodies the symbolic and sacred reappropriation of the traditional living space by inhabitants. However, the war has caused some erasure of the Muslim presence in the city. The political incidents and the eviction by the LTTE of the entire Muslim community questioned the peaceful coexistence between Jaffnese religious communities. In addition, the proselytizing of new Christian sects is a source of tension with the two major religions of the city which are forced to reconsider their attitude vis-à-vis the lower castes. 
C/ Reconstruction varies according to caste.

The compromise between LTTE and the government put an end to the embargo hanging over the Jaffna peninsula. Indeed, the reopening, in April 2002, of the A9 road, which had remained closed for twelve years, connected again Jaffna to Colombo. The detente between the belligerents enabled the devastated city to heal its wounds through the cement and other building materials that were sent back to Jaffna. However, there was a great heterogeneity in the rehabilitation of the different areas of the town.

Many of those who resettled in their original town, struggled to restore their homes. The government's support was far from sufficient. These were mainly NGOs and diaspora that enabled people to rebuild their homes. This financial assistance from the diaspora varied according to neighborhoods and especially castes. Thus, in neighborhoods occupied by Vellalar or Nalavar, it was essentially family solidarity that came into play. The exiled family regularly sent money to the family back home, allowing them to finance the rehabilitation work. In some fishermen's neighborhoods, there were both family and community solidarities. Indeed, members of the fishermen's caste diaspora created associations in their original neighborhoods bearing the name of their host country. These associations were able, with donations collected from expatriate members, to finance the restoration of community buildings such as schools, church or the purchase of fishing nets.

In contrast, castes like the Pallar, which did not manage to send members of their community abroad, experienced significant problems to rehabilitate their area. It was through the assistance of German Technical Cooperation (GTZ), which rebuilt their houses in cement, that the living conditions of this community relatively improved.

We observe a real spatial fragmentation in the reconstruction of neighborhoods, each community renovating its living space, according to the case: alone, with money from the diaspora or with the help of foreign organizations. If there is frustration among the poorest people, due to the slowness of the reconstruction of their homes, this latter is not the source of tensions between communities because each residents judges above all, its situation in relation with the members of his own caste.

\section{D/ The caste system: resurgence or the end in a near future?}

When we question Jaffnese on the caste problem, they generally say that it is no longer a current issue and that it is definitely a thing of the past. The end of the open discriminations against lower castes in Jaffna explains that majority of Jaffnese believes in good faith, that the caste system in the town no longer exists. The optimism displayed by the inhabitants of the city can be understood by the fact that this subject has become taboo since the banning of the caste system by the Tigers. The LTTE's intransigence on this issue did erase the main outward signs of discrimination and humiliation that contributed to the stigmatization of low castes. The municipality also had to accept the change of toponymy of certain places, having names considered offensive by the lower castes. Thus, several water wells changed their name, following the official request of the residents who refused names suggesting any caste affiliation.

Moreover, the reality of castes is less obvious to the younger generations. Education and money sent home by the diaspora enables Jaffnese to overcome the traditional activity associated with their caste and which was passed down from father to son. Thus, the Nalavar generally no longer practice their traditional activity of toddy extractors. Some occupy positions in municipal administration or have shops often financed by the expatriate members of the family. The rupture of the association of a caste to an occupation means the end of the socio-economic interdependance between the various castes. At the same time, the existence 
of a large diaspora is the source of a new factor of segmentation in the society. Indeed, caste having expatriate members enjoy an advantage over others. Thus, Vellalar and Nallavar from the diaspora helped their family members to leave the country or support them financially. Conversely, the Paraiyar, who had no financial capital to send some of their members abroad, do not benefit from this transnational solidarity. Financial support from the diaspora allows some inhabitants to develop economic activities favoring their emancipation.

The end of the caste system (discrimination, socio-economic interdependence) should not mask the persistence of the caste reality (endogamy, etc.). Indeed, in a society where the weight of tradition and family honor dominate, it is often the voice of the elders that counts. This is one of the reasons for the persistence of the caste system in the city. Indeed, even if by force of circumstances, the older generation had to bend to the will of the Tigers, putting aside caste distinctions publicly, they often keep in mind the system of hierarchy and honors in which they were raised.

It is particularly the issue of marriage that shows how important the reality of caste remains in the minds of Jaffnese. Indeed, most marriages are still arranged. Parents try to find for their children a spouse of the same caste and same religion as their family to avoid misalliance. They do not want to lose the ties that unite them to the caste community to which they belong. In this context, the love relationship between two people of different religions and especially different castes often encounter opposition from their families and even from the whole society. This was the case of a couple who met at the University of Colombo and who loved each other for five years ${ }^{13}$. The young Christian man from the fishermen's caste moved to London where he found work at the end of his studies. The girl, an Hindu from the Vellalar caste, returned with her family in Jaffna at the end of her studies. When the two families heard about their relationship, they were both adamantly opposed to it. The girl's family wanted her to be married to a man from the same caste and the same religion; logically they refused this misalliance. The young man's family wanted their child to marry a girl from their fishermen's neighborhood. Faced with the determination of the couple which did not want to marry someone else, the two families gave way without solving all the problems. While, initially, the groom's family refused any idea of asking a dowry, it eventually claimed 500000 rupees (3 270 euros) and a ground with a house. It was also asked from the bride to convert to Catholicism. The girl's family wanted to quickly marry their child who was already 28 years and to do the wedding in London and not in Jaffna to preserve the prestige of the family within the vellalar community. Faced with this request, the groom's family demanded that the girl's family come to formally propose marriage to their house and to organize the wedding in the church of their district. Despite their love, the couple reached a stalemate because of their religious and caste difference. If the practice of endogamous union reflects the weight of the reality of caste in the city, this later is questioned by the willingness of some of the youth who want to emancipate.

Finally, the persistence in the mentality of this caste system results in difficulties for a person to settle in the neighborhood of another caste. Thus, a notary ${ }^{14}$ confirmed that a number of people who bought houses from expatriate Vellalar, thanks to money sent by their relatives who had settled in the West, faced the hostility of the dissatisfied neighborhood. The Vellalar did everything to incite newcomers to leave. Under these conditions, few decide to settle out of the district where their family has lived for generations. Moreover, the fact that each caste has its own church helps to strengthen their solidarity bonds and they do not develop links with the Christian communities of other castes. Therefore, the mere fact of asking a Jaffnese where he lives, is still an effective way of getting to know his caste. The location of communities remains therefore still, in outline, faithful to the legacy of the Vedic segregated city. However, few cases of tensions related to the installation of persons in a neighborhood occupied by higher castes are significant. We observe an evolution of residential place choice that moves from a logic based on the distribution of communities by

13. This story was reported by a friend of the couple during an interview in March 2005 in Jaffna.

14. Interview conducted in Jaffna in February 2005. 
caste to a logic based on the law of the land market. If resistance to the mutation are significant, we can assume that the town is engaged in an inevitable process, especially since many expatriates do not intend coming back to settle in Sri Lanka and they are likely to sell their properties. The immediate post-war Jaffnese society remains very segmented but a process of identity desegregation by community belonging seems to have beging towards a more "traditional" social segregation layout by land prices in the city.

\section{Conclusion:}

The structure of the town before the war was marked by two models of segregated cities: that of the Vedic town, characterized by geographical distribution of castes and that of the dual colonial town with the opposition between the "European town" and the "Hindu town". The Jaffnese society was then known for the weight of the caste hierarchy. Despite spatial segregation, the different communities were socially and economically interdependent.

The conflict has transformed Jaffnese society and the profile of residents of the town. Indeed, communities that have financial resources or human resources, in terms of solidarity network, have often opted to leave the peninsula to Colombo or abroad. Conversely, the most modest groups have taken advantage of the cease-fire to reinvest their homes.

From a religious point of view, the confessional affiliation remains a key segmental factor in conferring landmarks, meaning and extended solidarity to a population ravaged by war. However, Muslims are still affected by their expulsion ordered by the LTTE and many are reluctant to return. Moreover, the establishment of evangelical churches are the source of tension with Catholics and Hindus because of their proselytizing.

The caste system was abolished but the caste reality continues to exist. However, the growing proportion of love marriages, as opposed to arranged, cast-based ones, in particular between persons of different castes, embodies, despite the difficulties faced by these couples, the real beginning of an evolution which challenges in its foundations, the caste reality at Jaffna. The attitude of the younger generations, who already evolve in a society where the profession is no longer related to caste, will play a decisive role in the existence or not of the caste system.

The immediate post-war town has a structure and functionality model that is different from the pre-war period. The caste identity segregation is thus in a disappearing. There is a disconnection with the end of the caste/profession interdependence that bound the various communities in Jaffna. Now, solidarity bonds, and even bonds of dependency, are transnational. Support of members from the diaspora plays a leading role in reconstruction, economic development of the town and the upward mobility of its inhabitants. Finally, if inhabitants live in the great majority in neighborhoods traditionally occupied by their caste, the process of spatial desegregation seems to be engaged. 
BALASUNDARAMPILLAI P., 2002, « Jaffna : Past, Present and Future a Development Perspective», in Jaffna Municipal Council, (Pon Vilha 50) Golden Year 1949-1999, Jaffna: Jaffna Municipal Council.

BENIT C. ET AL., 2005, «Fragmentations » in DORIER-APPRILL E. and P. GERVAISLAMBONY (eds), Vies citadines, 2005, Paris: Belin, 15-38.

DORIER-APPRILL E., 2002, « La fragmentation urbaine instrumentalisée par le politique : le cas de Brazzaville » in NAVEZ-BOUCHANINE F. (ed.), La fragmentation en question : des villes entre fragmentation spatiale et fragmentation sociale ?, 2002, Paris: L'Harmattan/Collection Villes et Entreprises, 347-359

DORIER-APPRILL E. et KOUVOUAMA A., C. APPRILL, 1998a, Vivre à Brazzaville : modernité et crise au quotidien, Paris: Karthala.

DORIER-APPRILL E. et A. KOUVOUAMA, 1998b, «Pluralisme religieux et société urbaine à Brazzaville », in Afrique contemporaine, $\mathrm{n}^{\circ} 186,58-76$

DUPONT V. et D. G. HEUZE, 2007, La ville en Asie du Sud : Analyse et mise en perspective, Paris: Editions de l'Ecole des Hautes Etudes en Sciences Sociales/ Collection Purusartha.

DUPONT V. ET F. LANDY F., 2003, « Ségrégation et territoire. De quoi parle-t-on? Réflexions à partir des expériences indiennes et sud-africaines », in GERVAISLAMBONY P. et al. (eds), Espaces arc-en-ciel : Identités et territoires en Afrique du Sud et en Inde, 2003, Paris: Karthala.

DUPONT V., 2000, « Delhi : Dispersion globale et micro-ségrégation », in DUREAU F. et al (eds), Métropoles en mouvement : une comparaison internationale, 2000, Paris: IRD/Collection Villes, 257-268

GERVAIS-LAMBONY P., LANDY F., OLFIELD S., 2003a, Espaces arc-en-ciel : Identités et territoires en Afrique du Sud et en Inde, Paris: Karthala.

GERVAIS-LAMBONY P., 2003b, « Discussion autour des notions de ségrégation et de fragmentation dans les métropoles sud-africaines », in GERVAIS-

LAMBONY P. et al.(eds), Espaces arc-en-ciel: Identités et territoires en Afrique du Sud et en Inde, 2003, Paris: Karthala, 257-270

GIRAUT F., HOUSSAY-HOLZSCHUSCH M., GUYOT S., 2008, Au nom des territoires! Enjeux géographiques de la toponymie, in L'espace géographique, n²-2008, 95-105

HASBULLAH S. H., 2001, Muslim Refugees: The forgotten people in Sri Lanka's ethnic conflict, Colombo: Research and Action For Social Development.

HOOLE et al. (eds), R., 1990, The Broken Palmyra, Claremont: Sri Lanka Studies Institute.

JAFFNA MUNICIPAL COUNCIL, 2002, (pon vilha 50) Golden year1949-1999, Jaffna: Jaffna Municipal Council.

JAFFNA MUNICIPAL COUNCIL, 1974, The Jaffna Municipal Council Silver Jubilee Souvenir, Jaffna: Jaffna Municipal Council.

KALAM M. A., 2003, «Identité, espace et territoire en Inde: une perspective anthropologique », in GERVAIS-LAMBONY P. et al. (eds), Espaces arc-en-ciel: Identités et territoires en Afrique du Sud et en Inde, 2003, Paris: Karthala, 69-81.

LAMBALLE A., 1985, Le Problème Tamoul à Sri Lanka, Paris: L'Harmattan.

LANDY F. (ed.), 2010, Dictionnaire de l'Inde contemporaine, Paris: Arman Colin.

LANDY F., 2002, L'Union indienne, Paris: Editions du Temps.

MADAVAN D., DEQUIREZ G., MEYER E. (eds), 2011, «Les communautés tamoules et le conflit sri lankais, Paris: L'Harmattan/Collection Géographie et Cultures.

MADAVAN D., 2011, «Géographie des 'espaces refuges' des Tamouls jaffnais depuis le début de la guerre à Sri Lanka», in Madavan D. et al. (eds), Les communautés tamoules et le conflit sri lankais, Paris: L'Harmattan/Collection Géographie et Cultures, 15-44

MADAVAN D., 2011, «Geography of 'Refuge Spaces' of Jaffnese Since the Beguinning of 
the War in Sri Lanka», in Géographie de la ville en guerre

http://geographie-ville-en-guerre.blogspot.com/2011/07/geographie-des-espaces-refuges-des.html

MADAVAN D., 2007, Jaffna et le conflit intercommunautaire à Sri Lanka, Paris: PRODIG/

Collection Grafigéo

MEYER E., 2001, Sri Lanka, entre particularisme et mondialisation, Paris: La Documentation Française/Collection Asie Plurielle.

NAVEZ-BOUCHANINE F., (2001), « Des villes entre fragmentation spatiale et fragmentation sociale: une approche critique de la notion de fragmentation », in Dorier-Apprill E. (ed.), Vocabulaire de la ville notions et références, 2001, Paris: Editions du Temps, 109-118

NUHMAN M.A., 2007, Sri Lankan Muslim Ethnic identity within cultural diversity, Colombo: ICES.

NUHMAN M.A., 2004, Undrestanding Sri Lankan Muslim Identity, Colombo: ICES.

PAUL L., 1997, La question tamoule à Sri Lanka, Paris: L'Harmattan.

PFAFFENBERGER B., 1982, Caste in Tamil Culture: The religious foundations of Sudra Domination in Tamil Sri Lanka, New-York: Marxwell School of Citizenship and Public Affairs Syracuse University.

ROSIERE S., 2007, « La modification coercitive du peuplement », in L'information géographique, 2007 vol. 71, 7-25

SPENCER J. (ed.), 1990, Sri Lanka, History and the roots of conflict, London: Routledge

TRATNJEK B., «Le nettoyage ethnique à Mitrovica. Interprétation géographique d'une double migration forcée » in Bulletin de l'Association des géographes français, vol. 83, $n^{\circ} 4$, décembre 2006.

WILSON A.J., 2000, Sri Lankan Tamil Nationalism. Its Origins and Development in the $19^{\text {th }}$ and $20^{\text {th }}$ Centuries, London: Hurst. 